\title{
Deploying Business Excellence - Success Factors for High Performance
}

\author{
Abstract \\ Purpose: This paper aims to improve our understanding of how organisations successfully deploy \\ business excellence $(\mathrm{BE})$ by comparing the tools and strategies implemented by organisations at \\ different levels of BE maturity.
}

Design/Methodology/Approach: The study used a combination of a questionnaire, discussion groups and interviews with respondents of private sector organisations across India, Japan, Republic of China, Singapore, and Thailand. These countries were selected due to them being considered as having the most advanced BE organisations in Asia by the Asian Productivity Organisation that commissioned the study. Once triangulated, the quantitative data was analysed through use of the IBM SPSS Statistical software package.

Findings: The study has shown that on average, organisations with higher BE maturity outperform their less mature counterparts. The study also revealed that organisations with a high BE maturity were more likely to use specific tools and were more likely to use some of these tools more effectively. Finally, the study identified differences in strategic approaches to BE between organisations with high and low BE maturity.

Research Limitations/Implications: Only 5 Asian countries were considered due to resource limitations. However, the study of 74 organisations represents one of the most comprehensive todate with 30 of these organisations being award winners.

Practical Implications: The findings offer guidance to those organisations wishing to progress from a low level of BE maturity to a more advanced level. The findings have already assisted the Asian Productivity Organisation and its 20 member countries in the development and implementation of strategic interventions at a regional and national level.

Originality/Value: No other study in Asia has been conducted on such a large sample of BE orientated organisations. The study was also unique in its focus on the tools and strategies that should be used for successful BE deployment. In addition, the study is one of only a few in Asia that has studied the results of BE on organisational performance.

\section{Introduction}

This paper aims to improve our understanding of how organisations deploy business excellence (BE). It investigates how organisations embrace and embed the core values and principles of $B E$ into their organisations, use $\mathrm{BE}$ models as a means for improvement and ultimately become recognised as a $\mathrm{BE}$ award winner. The potential of $B E$ in organisational development has been recognised in previous studies. There has been considerable research and many case studies (for example, Leonard and McAdam (2002), Ritchie and Dale (2000), Hakes (2011), Brown (2013), Blazey (2011), Mohammad et al. (2011), Naylor (1999), Talwar (2011)) showing how self-assessment against a BE model can 
impact organisational strategy and how executives are including BE results in their business planning process as well as using BE to identify areas for improvement. However, the author's are not aware of any research that compares the improvement tools and strategies used by organisations with an "awareness to progressing" level of BE maturity (which for simplification purposes we will refer to as "low" BE Maturity) to those with a "competence to advanced level of BE maturity" (which for simplification purposes we will refer to as "high" BE Maturity). While several studies have suggested that organisations go through different levels of development of BE (Dale and Smith, 1997, Saunders and Mann, 2007, Metaxas and Koulouriotis, 2014), there is little understanding of what these different levels imply with respect to actual implementation approaches. This study addresses this issue and, consequently, provides insights into how to deploy BE. Research was also conducted to investigate whether organisations with higher levels of BE maturity achieved better business results.

The research presented in this paper formed part of a larger project titled "Impact of Business Excellence/Quality Awards on Enterprises" (Mann, 2011). The research was undertaken by the Centre for Organisational Excellence Research and commissioned by the Asian Productivity Organisation (APO), an organisation that supports national productivity organisations (NPO) in 20 Asian countries. The APO considered that within Asia, India, Japan, Republic of China, Singapore, and Thailand were the most active in BE. As such experts from both the APO and each of the countries' NPOs formed the steering group for the project. The NPOs were the prime organisation responsible for promoting and encouraging the use of $\mathrm{BE}$ in their country therefore their input into sharing the direction of the research and the methodology used was most important. Previous research by Grigg and Mann (2008) has discussed the importance of the role of BE custodians (the organisations responsible for $\mathrm{BE}$ in a country) and the challenges faced.

As mentioned by Yong and Wilkinson (2001) and Arumugam et al. (2008), studies on BE tend to concentrate on western organisations with very few focusing on the issues and performance of their Asian counterparts. Haffer and Kristensen (2008) have pointed to the need for such research by stating the importance to understand the nature of $B E$ in the developing economies of Asia since it has been shown that BE performance can vary with levels of national development. This study, with the support of the APO, represented a rare opportunity to obtain access to many leading organisations in Asia. Data was obtained from a questionnaire, discussion groups and interviews conducted in the 5 selected countries. The APO and NPOs were responsible for encouraging BE orientated organisations to participate in the research. In total 74 organisations took part with 30 of the 74 (40.5\%) having won a national BE award.

The paper begins with a literature review of relevant research on BE deployment, followed by the aims of the research, methodology, results, discussion and conclusion.

\section{Literature Review}

A substantial literature review was undertaken and is structured as follows:

1. What is $\mathrm{BE}$ - this section provides a short review of $\mathrm{BE}$ and its history. 
2. Approaches to BE deployment - this section includes a review of a) the improvement tools used by organisations to deploy $B E$, and $b$ ) the strategies used by organisations for deploying and sustaining $\mathrm{BE}$.

3. Approaches to assessing BE maturity - this section includes a review of the different approaches used for assessing BE maturity.

4. Impact of $B E$ - this section provides a review of the impact of $B E$ at both organisational and societal level.

\subsection{What is BE?}

Various opinions exist about the evolution of BE and in particular, its relationship with TQM. While some authors such as Dahlgaard-Park (2011) suggested that BE replaced TQM, others such as Wang and Ahmed (2001) have considered them to be separate entities, even though there are many similarities. TQM became popular in the mid to late 1980 s as a means for raising the competitiveness and productivity of western organisations in response to the competition from Japan and emerging economies such as South Korea. From the first use of the term TQM in a paper in 1984 (Rehder and Ralston, 1984) the understanding of TQM grew and was clarified further with the development of widely accepted TQM Models, most notably the Malcolm Baldrige Criteria (later known as the Baldrige Criteria for Performance Excellence) and the EFQM Excellence Model, introduced in 1987 and 1991 respectively. These models and associated award schemes were developed by the United States government and the European Foundation of Quality Management respectively, in order to both encourage and improve quality standards in their regions.

Asian countries followed a similar path with South Korea and the Republic of China developing comparable models and award schemes in 1989 and 1990 (Mann et al., 2011b). India followed soon after, with the Confederation of Indian Industry giving its first award (based on the EFQM model) in 1994 and the Indian Merchant's Chamber's award (based on the Baldrige Criteria for Performance Excellence) in 1996. Singapore, Japan and Thailand then announced their first award winners in 1994, 1996 and 2001 respectively, with all of these awards being based on the Baldrige Criteria.

Adebanjo (2001) states that around the mid-1990s the term TQM was replaced with BE, and the quality models mentioned above were renamed Business Excellence Models (BEMs). The main reason for this was the need to differentiate BE from "old TQM", which had become an ambiguous term due to the large number of different interpretations and methods of implementation (Mann, 2008). It is believed that this lack of clarity and understanding of TQM contributed to the high number of reported TQM failures (Black and Revere, 2006, Evans and Lindsay, 2005).

BE can be defined as "excellence in strategies, business practices, and stakeholder-related performance results that have been validated by assessments using proven business excellence models (BEMs)" (Adebanjo and Mann, 2008). The BEMs were created using core values and principles that are deemed crucial in encouraging high business performance. The core values and principles of excellence are similar between the various models that exist, as shown by table 1 which compares the key principles of the 2 most popular BEMs (Baldrige and EFQM). 


\begin{tabular}{|c|c|}
\hline EFQM BE Model & Baldrige BE Model \\
\hline Creating a Sustainable Future & Visionary leadership \\
\hline Adding Value for Customers & Customer-driven excellence \\
\hline Developing Organizational capability & Organizational and personal learning \\
\hline Managing with Agility & Valuing workforce members and partners \\
\hline Succeeding through the Talent of People & Agility \\
\hline Harnessing Creativity \& Innovation & Focus on the future \\
\hline Sustaining Outstanding Results & Managing for innovation \\
\hline \multirow[t]{4}{*}{ Leading with Vision, Inspiration \& Integrity } & Management by fact \\
\hline & Societal responsibility \\
\hline & Focus on results and creating value \\
\hline & Systems perspective \\
\hline
\end{tabular}

Table 1: Key Principles of the EFQM BE Model and the Baldrige BE Model (adapted from EFQM (2012), and (National Institute of Standards and Technology, 2013b))

Each BEM has its own set of criteria based on these key principles and these criteria are used to assess organisations in terms of their level of excellence; those that incorporate the values and principles of BE are considered "BE organisations" (Mann et al., 2011b). Figure 1 details the Baldrige Criteria for Performance Excellence.

\section{[INSERT FIGURE 1 HERE]}

In essence, organisations are assessed on their level of BE deployment using the criteria of a BEM to question how their organisation is managed and what results are being achieved. Many countries provide different levels of BE award based on an organisation's BE score and, in the majority of cases, those that score over 650 out of 1000 points are considered to be "world-class" and eligible for the most prestigious award; the national BE award. At the time of writing, 86 countries have some form of national BE award. According to Mohammad and Mann (2010), 40 of these awards are based on the EFQM model, 27 are based on the Baldrige Criteria for Performance Excellence, 18 have their own bespoke models and 1 utilises multiple models.

\subsection{Approaches to BE Deployment}

Organisations that choose to implement BE are typically faced with the option of whether to apply for BE awards or simply implement BE solely for the purpose of practice. A number of studies have discussed the differences between organisations that have won BE awards and organisations that have chosen not to apply for awards. While Oakland and Tanner (2008) argued that fulfilling award criteria can detract organisations from other business goals, other researchers including Kumar et al. (2009), Jacob et al. (2004) and Hendricks and Singhal (1997) found that organisations that won BE awards achieved better business results, on average, than organisations that do not apply for the awards. However, it can be argued that not all organisations that choose not to apply for awards lag award winners in term of performance. It is possible that some organisations do not wish to be subject to the time, effort and distraction that the award process can encompass (Lee, 2002). 
According to Vora (2013), the implementation of BE is a major effort that requires substantial change management. The implication is that $B E$ itself is not an independent practice but an initiative which can enable organisations to convert resources or efforts into performance. Studies including those by Saunders et al. (2008) and Bolboli and Reiche (2013) have identified pre-requisites or strategies for BE success. These include organisation integration capabilities, appropriate corporate strategy, access to external resources and knowledge, integration of human factors and organisational adaptability. Consequently, it is important to understand how organisations deploy BE as well as have an understanding of the types of improvement tools and techniques that $\mathrm{BE}$ organisations could be using. These improvement tools and techniques are facilitated by the aforementioned organisational resources that enable BE. This led to a review of the literature to find out which tools and strategies should be included in a questionnaire of BE organisations.

\subsubsection{The tools used by organisations to deploy BE}

When reviewing the literature the authors found a useful classification system as described by Van der Wiele et al. (2007) that split improvement initiatives into approaches, systems, tools and/or techniques:

- Approaches require some form of resource (for example training), strategic planning and commitment from senior management in order to be successfully adopted.

- Systems involve written documentation in terms of instructions and procedures and are used to manage and control an operation.

- Tools are devices that have both a role and an application. Tools often have a narrow focus and are usually used on their own.

- Techniques are usually a collection of tools that have a wider application and scope.

This led to using a similar system that enabled the study of improvement tools (which grouped together Tools and Techniques) and strategies (which grouped together Approaches and Systems).

The literature showed that there was no consensus on the number or types of tools to use or how to classify them. This was perhaps no surprise as there are over 900 to choose from (Adebanjo and Mann, 2008, Harrington and Lomax, 2000).

Mohammad et al. (2011) identified 35 improvement initiatives as important for business excellence orientated organisations; these included balanced scorecard, business process reengineering, corporate social responsibility system, customer relationship management (CRM), knowledge management, lean, mission and vision statement and six sigma. Mann (2008) identified 65 tools as important to Total Quality Management, including customer surveys, quality cost, benchmarking, quality function deployment (QFD) and employee suggestion scheme. In terms of current adoption, a study by Adebanjo et al. (2010) showed that mission and vision statement, customer surveys, SWOT analysis, informal benchmarking, quality management system, improvement teams and employee suggestion scheme were the most popular techniques whereas quality management system, improvement teams, customer surveys, business process reengineering and plan do check act (PDCA) were seen as the most effective by practitioners. Rigby and Bilodeau (2013) undertake a yearly global study of the 25 most popular and effective improvement tools for Bain and Co.; these include Balanced Scorecard, Benchmarking, Business Process Reengineering, Customer Relationship 
Management, Open Innovation, Supply Chain Management, Employee Engagement Surveys, Change Management Programs, Mission and Vision Statements, Outsourcing and Total Quality Management.

As well as reviewing the literature on studies of improvement tools and strategies the authors reviewed a number of case studies on the improvement tools and strategies used by BE award winners. For example, Lockheed Martin (winners of the Malcolm Baldrige Award 2012 for manufacturers) used Benchmarking, Mission and Vision Statement, Lean, Six Sigma, Employee Surveys, Customer Surveys, CRM, Knowledge Management, Quality Cost, QFD, SWOT and MESA (winners of the Malcolm Baldrige Award 2012 for small businesses) used Benchmarking, Balanced Scorecard, Employee Suggestion Scheme, Environmental Management System, Improvement Teams, Knowledge Management, Lean, Mission and Vision Statement, PDCA, Quality Management System and SWOT Analysis (National Institute of Standards and Technology, 2013a).

As other scholars have already addressed the definitions of improvement tools and strategies, it is not the intention of this paper to do likewise; table 2 gives a summary of these tools and examples of scholars that have provided definitions.

\begin{tabular}{|l|l|}
\hline Scholar & Improvement Tool / Technique Defined \\
\hline Slack et al. (2013) & $\begin{array}{l}\text { Balanced Scorecard, Business Process Reengineering (BPR), corporate social } \\
\text { responsibility (CSR), Lean, PDCA, QFD, Quality Management System, Six Sigma, } \\
\text { TQM and 5S }\end{array}$ \\
\hline Oakland (2003) & $\begin{array}{l}\text { Balanced Scorecard, Improvement Teams, Knowledge Management, Mission } \\
\text { and Vision Statement, PDCA, QFD, Quality Management System, Six Sigma and } \\
\text { TQM }\end{array}$ \\
\hline Rigby (2011) & $\begin{array}{l}\text { Balanced Scorecard, BPR, Knowledge Management, Mission and Vision } \\
\text { Statement and TQM }\end{array}$ \\
\hline Dale (2003) & $\begin{array}{l}\text { BPR, Lean, PDCA, QFD, QMS, Six Sigma and TQM } \\
\text { QFD, Six Sigma and TQM }\end{array}$ \\
\hline Foster (2010) & Balanced Scorecard, Six Sigma, PDCA, QFD, SWOT and TQM \\
\hline Sower (2011) & Balanced Scorecard, Customer Surveys, Knowledge Management, Lean, PDCA, \\
\hline
\end{tabular}

Table 2: Examples of scholars that have defined the purpose of a variety of Improvement Tools / Techniques

Given the vast array of tools available to organisations it was unsurprising that there was no consensus on the tools to use or research based evidence that pointed to which tools to use for BE adoption. However, some tools appeared more frequently in the research and/or were reported to have high levels of effectiveness. This led to the identification of 60 tools and after careful review of the literature alongside discussions with the APO/NPO based on their experience of tools used in their countries, a final selection of 24 tools were included in the study.

The results of this literature review are important for two reasons. Firstly it identified that little research has been conducted on the tools used for BE deployment; although previous research has 
highlighted various improvement tools that are available to organisations, few studies have looked into the precise tools that should be used to successfully deploy BE within an organisation. Secondly, the review identified the tools to be considered for inclusion in the study.

\subsubsection{The strategies used by organisations for deploying and sustaining BE}

Organisations that are pursuing BE usually have a strategy and a system by which they intend to improve their BE score year on year. This may involve initiatives such as setting up a steering group and improvement teams, allocating responsibility for each BE category to an individual or team, implementing an improvement system, deciding on which improvement tools to use and in what situation, undertaking regular BE assessments or conducting education and training for all members of staff. According to Bolboli and Reiche (2013), organisations that follow a structured approach to implementing BE are more likely to have a sustainable BE programme. Similar to the improvement tools used to implement and sustain $\mathrm{BE}$, the strategies used usually differ considerably between organisations. A study by Saunders et al. (2008) pointed to the critical role that BE custodians, the administrators of national $\mathrm{BE}$ awards, play in influencing organisations on the tools and strategies to use. BE custodians offer advice and training to organisations wishing to deploy BE with activities such as tours of best practice organisations, publications, on-line information databases of BE cases studies, seminars, conferences, and workshops being considered the most useful.

At some point all BE organisations will assess their systems and performance against a BE model to identify strengths and opportunities for improvement. Porter and Tanner (2004) describe the generic process of assessment that is used for award assessments and for comprehensive selfassessments, see figure 2 . This process is described below, but in most cases organisations would use simpler approaches such as pro-forma, survey and workshop self-assessments. The first step involves selecting the most appropriate excellence model (for example EFQM or Baldrige) to work to. The second step involves forming an assessment team, members of which should be drawn from a broad cross-section of organisational units. The next step involves collecting the data; here the organisation writes a submission document that describes the organisation's aims, processes, systems and results which addresses these in the context of the BE criteria. The submission document is then scrutinised by each of the assessors who individually identify strengths, areas for improvement and site-visit issues which are then recorded in a scorebook. The scoring is conducted using the guidelines from the selected excellence model and once the individual assessment is complete, assessors come together to exchange opinions and reach consensus on strengths, areas for improvement, site-visit issues and scores. A feedback report is then created which represents a final analysis of the organisation based on all inputs from the assessment team and contains the organisation's key strengths and areas for improvement. Finally, the feedback report is used to create an action plan, which involves both short and long-term plans for improvement.

\section{[INSERT FIGURE 2 HERE]}

Strategies for deploying BE have been described by a number of researchers; for example George et al. (2003) documented how a local authority in the UK successfully implemented the EFQM excellence model. The process used was similar to that described by Porter and Tanner (2004). In another case study, Tossaint (2010) explains how Dutch manufacturer Philips deployed and 
continues to sustain BE. Philips began using BE in 1999, the catalyst being their heavy involvement in the establishment of the EFQM. They quickly adopted a customised version of the EFQM model (known as the Philips Business Excellence Model) for strategic purposes but also to assess all organisational units on a yearly basis. Philips used quality improvement teams, six-sigma, balanced scorecard, lean, mission and vision statement and employee surveys among other tools in order to obtain improvement.

Another study identified strategies of BE adoption by asking CEOs and management representatives from Singaporean organisations for their opinions on the critical success factors required to successfully adopt BE (Spring Singapore, 2010). The factors with the highest mean results are shown in table 3. Of interest is that the majority of the high-ranking results are people-based, suggesting that cultural aspects play a significant role in successful BE adoption.

\begin{tabular}{|l|c|c|}
\hline \multicolumn{1}{|c|}{ Factor } & \multicolumn{2}{c|}{$\begin{array}{c}\text { Mean (1 = Strongly Disagree, } \mathbf{5}=\text { Strongly } \\
\text { Agree) }\end{array}$} \\
\cline { 2 - 3 } & CEO & $\begin{array}{c}\text { Management } \\
\text { Representative }\end{array}$ \\
\hline Top management commitment and leadership to drive BE journey & 4.87 & 4.86 \\
\hline Top management's desire to grow the organisation & 4.76 & 4.74 \\
\hline Transparency and open communications throughout the organisation & 4.53 & 4.47 \\
\hline Ability to manage change & 4.53 & 4.51 \\
\hline Having staff who believe in the BE model to drive the BE effort & 4.45 & 4.46 \\
\hline Getting buy-in from staff & 4.40 & 4.46 \\
\hline Teamwork throughout the organisation & 4.53 & 4.56 \\
\hline Having disciplined and determined staff & 4.40 & 4.30 \\
\hline Giving rewards and recognition for supporting the BE model & 3.93 & 3.93 \\
\hline $\begin{array}{l}\text { Ability to entrench learning from BE journey into work processes and } \\
\text { procedures }\end{array}$ & 4.33 & 4.32 \\
\hline Having a culture of continuous improvement & 4.62 & 4.65 \\
\hline
\end{tabular}

Table 3: Critical Success Factors for BE adoption (adapted from Spring Singapore (2010))

A study by Bauer et al. (2005) found that a less complex organisational structure leads to a more successful implementation of $\mathrm{BE}$, with less formalisation in terms of written rules and supervision also contributing to increased success. Some authors have begun developing prescriptive BE models with the aim of aiding practitioners in the adoption of BE concepts and principles (Yang, 2009, Dahlgaard et al., 2013) whereas others suggest that organisations may wish to consider developing their own "hybrid" excellence model whereby the organisation selects the parts of a model that are most appropriate to the organisation's current situation (Porter and Tanner, 2004). This again suggests that there is no "one size fits all" methodology for deploying and sustaining BE and that most organisations develop their own strategy for internal improvement, but then use external assessments against the various BEM criteria in order to gain further insights into how to improve.

The review of the above literature achieved the following: firstly it identified different strategies used for BE implementation. Secondly, it showed that these differences appear to be influenced by factors such as the organisation's level of maturity, its business environment and the BE services which were available from the local BE custodian. Thirdly, the review aided in framing the questionnaire, discussion group, and CEO interview questions on BE strategies. 


\subsection{Approaches to assessing BE Maturity}

There has been much debate over the methods by which organisations assess their current level of BE maturity. Many organisations simply state their BE score as an indicator of their maturity level, however the issue with this approach is that most organisations do not have their scores independently verified on a regular basis. Similarly, even if organisations have an independent assessment by an award body, the score may not be revealed unless they win an award and even then it may only be given as a scoring range. There has therefore been a number of different approaches suggested by scholars over the years (Crosby, 1979, Dale, 1996, Huq and Stolen, 1998, Garvin, 1991, Kaye and Dyason, 1995, Peters, 1994, Prabhu et al., 2000). Oakland and Tanner (2008) used the Leadership Excellence Model suggested by Kanji (2002) for assessing BE maturity whereas Dale and Smith (1997) created a 7-stage maturity process as shown below:

- Stage 1: Unaware - the organisation is unaware of concepts and practices of $B E$,

- Stage 2: Uncommitted - the organisation has an understanding of BE but no programme is implemented,

- Stage 3: Initiators - the organisation begins initiating basic elements of $B E$,

- Stage 4: Drifters - the organisation drifts from one BE initiative to another and achieves short-term results,

- Stage 5: Improvers - an organisation-wide BE initiative is driven by small number of individuals,

- Stage 6: Award Winners - a BE initiative is implemented alongside the business strategy and involves all employees,

- Stage 7: World Class - BE is fully integrated with business strategy and becomes a way of life.

Building on this, Saunders and Mann (2007) produced a BE maturity matrix which allows an organisation to assess their current stage of BE maturity. This matrix uses four levels of BE maturity (starting, progressing, mature and excellent) and relates them to the 7 key criteria for performance excellence as defined by the Malcolm Baldrige National Quality Award (National Institute of Standards and Technology, 2012). This matrix was developed further by Mann et al., 2012b and for illustration purposes part of the matrix is shown in Table 4.

\begin{tabular}{|c|c|c|c|c|c|}
\hline No & Item & Starting & Progressing & Advanced & Excellent \\
\hline 1 & Leadership & $\begin{array}{l}\text { We don't have a } \\
\text { vision, mission, } \\
\text { strategic direction and } \\
\text { performance } \\
\text { expectations or they } \\
\text { are out of date. We } \\
\text { rarely review the } \\
\text { negative } \\
\text { environmental and } \\
\text { community impact of } \\
\text { our products, services, } \\
\text { processes and sites. }\end{array}$ & $\begin{array}{l}\text { We have a vision, } \\
\text { mission, strategic } \\
\text { direction and } \\
\text { performance } \\
\text { expectations that we are } \\
\text { happy with but these } \\
\text { are only known by a few } \\
\text { members of staff. We } \\
\text { sometimes review the } \\
\text { negative environmental } \\
\text { and community impact } \\
\text { of our products, } \\
\text { services, processes and } \\
\text { sites. }\end{array}$ & $\begin{array}{l}\text { Our vision, mission, } \\
\text { strategic direction and } \\
\text { performance } \\
\text { expectations are } \\
\text { communicated and } \\
\text { known by most } \\
\text { employees. We } \\
\text { regularly review the } \\
\text { negative } \\
\text { environmental and } \\
\text { community impact of } \\
\text { our products, services, } \\
\text { processes and sites. }\end{array}$ & $\begin{array}{l}\text { Our vision, mission, } \\
\text { strategic direction and } \\
\text { performance expectations } \\
\text { are communicated and } \\
\text { known by all employees } \\
\text { and regularly reviewed. } \\
\text { We address and minimise } \\
\text { the negative environmental } \\
\text { and community impact of } \\
\text { our products, services, } \\
\text { processes. Our leadership } \\
\text { approach is regularly } \\
\text { reviewed for effectiveness. }\end{array}$ \\
\hline
\end{tabular}




\begin{tabular}{|c|c|c|c|c|c|}
\hline 2 & $\begin{array}{l}\text { Strategic } \\
\text { Planning }\end{array}$ & $\begin{array}{l}\text { We do not have an } \\
\text { overall strategic plan. } \\
\text { We don't have } \\
\text { missions, plans and } \\
\text { performance targets } \\
\text { cascaded to our } \\
\text { departments, teams, } \\
\text { and employees. }\end{array}$ & $\begin{array}{l}\text { We have a strategic plan } \\
\text { but use an informal } \\
\text { approach to its } \\
\text { development - } \\
\text { therefore we don't } \\
\text { conduct a thorough } \\
\text { review of our strengths } \\
\text { and weaknesses based } \\
\text { on relevant information } \\
\text { from our customers, } \\
\text { competitors and on } \\
\text { potential and emerging } \\
\text { markets. Most of our } \\
\text { departments, teams, } \\
\text { and employees have } \\
\text { missions, plans and } \\
\text { performance targets } \\
\text { that are aligned to our } \\
\text { key strategies. }\end{array}$ & $\begin{array}{l}\text { We have a strategic } \\
\text { plan and use a formal } \\
\text { approach to its } \\
\text { development - } \\
\text { therefore we conduct } \\
\text { a thorough review of } \\
\text { our strengths and } \\
\text { weaknesses based on } \\
\text { relevant information } \\
\text { from our customers, } \\
\text { competitors and on } \\
\text { potential and } \\
\text { emerging markets. All } \\
\text { of our departments, } \\
\text { teams, and employees } \\
\text { have missions, plans } \\
\text { and performance } \\
\text { targets aligned to our } \\
\text { key strategies. }\end{array}$ & $\begin{array}{l}\text { We have a strategic plan } \\
\text { and use a formal approach } \\
\text { to its development - } \\
\text { therefore we conduct a } \\
\text { thorough review of our } \\
\text { strengths and weaknesses } \\
\text { based on relevant } \\
\text { information from our } \\
\text { customers, competitors } \\
\text { and on potential and } \\
\text { emerging markets. All our } \\
\text { departments, teams, and } \\
\text { employees have missions, } \\
\text { plans and performance } \\
\text { targets aligned to our key } \\
\text { strategies. Our strategic } \\
\text { planning approach is } \\
\text { regularly reviewed for } \\
\text { effectiveness. }\end{array}$ \\
\hline
\end{tabular}

Table 4: BE Maturity Matrix (Saunders and Mann, 2007; Mann et al, 2012b)

Mohammad et al. (2011) suggest another maturity model whereby organisations advance through 4 stages of maturity; beginning, progressing, advanced and role model. Priorities for organisations at the beginning stage tend to involve finding solutions for current problems, with the focus being on short-term results and here the management style is described as "reactionary" (Dale and Lascelles, 2007). Tools and techniques recommended for this stage include balanced scorecard, lean, quality management system, benchmarking, mission and vision statement and improvement teams. As organisations improve their quality levels, they move to the progressing stage, where they tend to concentrate more on the prevention of non-conformances via activities such as improved product and process design and advanced quality planning. Organisations at this stage are encouraged to use more advanced techniques such as six sigma, knowledge management, BPR and environmental management systems. Organisations that progress beyond this are considered to be in the advanced stage; these organisations see excellence as a company-wide priority that involves everyone and can focus more on corporate social responsibility (CSR) systems. Beyond this stage, organisations are deemed to be "role models"; these organisations have fully integrated continuous improvement into the organisation.

The review above has clearly indicated that with respect to the deployment of $\mathrm{BE}$, organisations have typically achieved different levels of maturity and competence. Therefore, for the purposes of this study, it was necessary to differentiate between the different levels of competence and maturity. Based on discussions with the APO/NPO steering group, it was decided that a 5-level classification that combines elements of the models by Dale and Smith (1997) and Mann et al. (2012b) be developed. The 5 classification levels developed and agreed upon were:

- Awareness - There is some awareness of "business excellence" but no one in the organisation has been trained in BE. Management are not sure how BE can be applied within the organisation.

- Understanding - Management understand BE and how it can be applied. Key members of staff have attended training courses in BE.

- Progressing - The organisation has conducted at least one assessment against a BE model and taken steps to improve their systems and performance. Many of the organisation's staff have attended training courses in BE. 
- Competence - The organisation has undertaken a few BE assessments, refined its assessment method, and can demonstrate improved performance as a result of the BE approach. The organisation uses the model as a reference model to guide its improvement efforts. Most of the organisation's staff are aware of the model and use it as a means to assess and improve the area of the business that they work in.

- Advanced - The BE principles on which the models are based are embedded within the organisation. The organisation has undertaken many assessments, refined its assessment method and can demonstrate improved performance year on year as a result of the $\mathrm{BE}$ approach. All of the organisation's staff are aware of the model and follow BE principles in their daily work.

For the author's study the number of organisations participating was not large enough to study all five stages of maturity. Therefore, organisations in the Awareness, Understanding or Progressing stage were grouped together as organisations with "Low BE Maturity", and those in the Competence or Advanced stage were considered as organisations with "High BE Maturity".

The results of this literature review were important in identifying how to measure BE maturity as well as how to classify the maturity of an organisation.

\subsection{Impact of BE}

The literature review suggests that adopting BE affords organisations many benefits. For example, Hendricks and Singhal (1997) found that organisations that had received a BE award achieved a higher operating income, had a better sales growth, were better at controlling costs, had increased capital expenditures and had higher growth in both employment and total assets than those organisations that had not received an award. Other scholars have found that regardless of sector or size of organisation, implementing BE has a positive impact on organisational learning, overall organisational and operational performance and innovation performance (Hung et al., 2011, Valmohammadi, 2011, Salaheldin, 2009). Others still have found that those organisations that achieved the EFQM Excellence Award outperformed those that didn't in the areas of share value, revenue and sales, reduction in costs and operating income (Boulter et al., 2005) as well as job satisfaction (Tutuncu and Kucukusta, 2009). Kuruppuarachchi and Perera (2010) found that BE adoption has a positive impact on operations performance, cost performance, delivery performance, organisational flexibility and technology management, while Kumar et al. (2009) found BE adoption had a positive impact on employee relations, operating procedures, customer satisfaction and financial results. Furthermore, Macleod and Baxter (2001) found that BE initiatives can have a positive impact on improvement initiatives; this suggests that maturity in $\mathrm{BE}$ can lead to success in other improvement initiatives. However, other studies have identified shortcomings with BE models; Asif et al. (2011) stress that the models fail to take into account organisational sustainability while Dahlgaard et al. (2013) suggest that BE models are too cumbersome and suffer from a lack of focus. In summary, there is general agreement that BE does have a positive impact however there are opportunities to improve the models and, in particular, more information is required on how $B E$ has been implemented in organisations that have achieved excellent results.

Much of the literature on the impact of BE in organisations is based on western organisations. In terms of the impact of BE in Asian organisations, a study by Mann et al. (2011a) showed that those 
organisations that had adopted BE considered themselves better off as a result. Respondents were asked to rate their performance in terms of leadership, strategic planning, measurement and analysis, customer focus, people management and process management both before and after BE adoption. Using a scale of 1 to 10 there was at least a 2-point improvement for each category post adoption. Similarly, respondents were asked to rate their business results in terms of product and service results, customer focused results, financial and market results, workforce related results, process effectiveness results, leadership results and social responsibility results both before and after BE adoption. Again, there was at least a 2-point improvement in each of the categories post adoption.

Another study on the impact of BE in Asian organisations was conducted by Spring Singapore (2010) who asked CEOs and other management representatives in Singaporean organisations for their opinions on the impact of BE. The results indicated that the vast majority of respondents strongly believed that $\mathrm{BE}$ improved the competitiveness and business performance of their organisation. They also strongly believed that BE adoption led to improved internal management systems and practices, improved communication, increased teamwork effectiveness, increased commitment to continuous improvement, increased clarity of roles within the organisation, increased recognition of brand name and the identification of gaps and areas of improvement within the organisation.

To further highlight the potential performance improvements that BE offers organisations, the study reviewed the improvements obtained by Baldrige winners in 2012 (National Institute of Standards and Technology, 2013a). These improvements were substantial, as can be seen by the summary in table 5 .

\begin{tabular}{|c|c|}
\hline Organisation & Improvements Obtained \\
\hline $\begin{array}{l}\text { Lockheed Martin } \\
\text { (Winner of } \\
\text { Baldrige Award for } \\
\text { Manufacturing } \\
\text { 2012) }\end{array}$ & $\begin{array}{l}\text { - } 1029 \% \text { increase in deliveries }(2001-2011) \\
\text { - } \quad 86 \% \text { increase in output }(2007-2011) \\
\text { - } \quad \text { Over } 99.998 \% \text { up-time }(2007-2011) \\
\text { - } \quad 100 \% \text { of customers "Definitely / Probably would select organisation for future business" } \\
\text { - } \quad 28 \% \text { growth in sales per employee }(2007-2011) \\
\text { - } \quad \text { Organisation is over } 500 \% \text { better than industry average and over } 350 \% \text { better than private } \\
\text { industry average on the OSHA Recordable Incident Rate } \\
\text { - } 65 \% \text { decrease in recordable incidents }(2001-2011)\end{array}$ \\
\hline $\begin{array}{c}\text { MESA } \\
\text { (Winner of } \\
\text { Baldrige Award for } \\
\text { Small Business } \\
\text { 2012) }\end{array}$ & 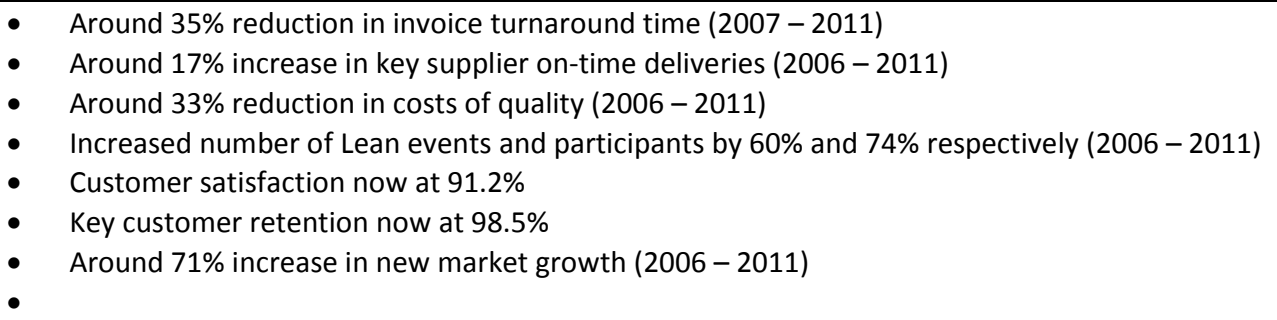 \\
\hline $\begin{array}{c}\text { City of Irving, } \\
\text { Texas } \\
\text { (Winner of } \\
\text { Baldrige Award for } \\
\text { Non-profit 2012) }\end{array}$ & $\begin{array}{ll} & 24.5 \% \text { reduction in crime }(2007-2011) \\
\text { - } & \text { Reduced number of water samples containing bacteria to } 0 \%(2007-2011) \\
\text { - } & \text { Drinking water compliance at } 100 \% \text { year-on-year }(2007-2012) \\
\text { - } & \text { Reduced pot hole response time to } 1 \text { day }(2008-2012) \\
\text { - } & \text { Emergency services preparedness training compliance scores } 100 \% \text { year-on-year }(2007-2012) \\
\text { - } & \text { nncrease in number of residents rating i) appearance of city, ii) code enforcement, iii) } \\
\text { - } & \text { neighbourhood safety and iv) condition of major streets as good or excellent (2007 - 2012) } \\
\end{array}$ \\
\hline
\end{tabular}

Table 5: Improvements Obtained by three Baldrige Award Winners in 2012 (Adapted from NIST (2013a)) 
This literature review has shown some of the key research that has been conducted on the impact of $\mathrm{BE}$, the majority of which has highlighted the substantial benefits available to organisations that pursue BE. However, it is clear that little research has been undertaken on BE within Asian organisations. Furthermore, no research in Asia has been found that involved investigating levels of BE maturity with business results.

\subsection{Research Aims}

Based on the review of literature, the aims of this research were identified as follows:

- To identify the difference in organisational performance between highly mature and less mature BE organisations,

- To identify the differences in BE deployment in terms of the tools and strategies used between highly mature and less mature BE organisations.

In support of these aims, 4 research questions were proposed and investigated:

1. Do highly mature BE organisations perform better than their less mature counterparts?

2. Do the BE tools used by organisations depend on their level of BE maturity?

3. Does the effectiveness of BE tools vary depending on the level of BE maturity?

4. Do BE strategies used by organisations depend on their level of BE maturity?

\section{Methodology}

The study, which took place in $2009-2010$, utilised a mixed method research approach. This consisted of a questionnaire, discussion groups carried out in different countries with senior managers from organisations that have adopted $\mathrm{BE}$, and semi-structured interviews conducted with senior managers of some of the organisations in different countries. The NPOs in each of the countries were integral to the success of each of the study phases. Specifically, the NPOs encouraged organisations in their respective countries to complete the questionnaire and also facilitated access to both the organisations that participated in the discussion groups as well as those involved in the interviews. Furthermore, a team of experts from the NPOs were involved in the design of the questionnaire and its translation into local languages.

The mixed method research approach ensured that a large amount of rich qualitative and quantitative data was collected, which allowed for an in-depth investigation into the research questions. Each of the phases of research is now explained further.

\subsection{Questionnaire}

The questionnaire was designed by the researchers using input from a steering group of experts from the APO and the five NPO countries/regions participating in the study (India, Japan, Republic of China, Singapore and Thailand). 
The NPO decided that the organisations selected to participate in the questionnaire should be forprofit organisations as the NPO's prime role is to support the private sector. In each country, National Business Excellence Award winners were strongly encouraged to participate as these were likely to be the most mature in $\mathrm{BE}$. In addition, other organisations with at least a basic knowledge of $\mathrm{BE}$ were encouraged to participate. The questionnaire specified that it should be completed by "the person (or team of people) that have a good understanding of your organisation's BE approach and its impact on your organisation's performance. This person(s) is likely to be a member of your senior management team".

The questionnaire was made available to participants in both online and hard copy format, and was translated into Japanese, Thai and Chinese. In total, 74 completed questionnaires were returned, 30 of which were either current or previous National BE Award Winners. The response from 30 award winners represents a large sample (about $60 \%$ ) of eligible private sector award winners from these countries; this high proportion ensured that many of the participating organisations would have a high level of BE maturity. The high proportion of award winners that participated in the study improved the validity and reliability of the findings by reducing sampling errors whereby a sample will not be representative of the larger population. To improve the validity and reliability of the data participant organisations were encouraged by their respective NPOs to attend a workshop prior to completing the questionnaire. The workshop enabled the researchers to clarify the meaning of questions on the questionnaire, thereby ensuring that the questions were answered as accurately as possible. The validity and reliability of the results were also improved by the mixed-methods approach adopted by the study - the combination of a questionnaire, structured interviews and discussions with focus groups provided triangulation of multiple sources of information (Patton, 1987). According to Gerring (2006), the use of multiple sources of information enables increased verification of inferences and findings.

\subsection{Discussion Groups}

Discussion groups took place in all five countries/regions during BE workshops organised by the respective NPOs. Six discussion groups occurred in India, 4 each in Singapore, Republic of China and Thailand and 3 in Japan. The groups comprised between 4 and 8 senior managers (from different organisations) whose role involved responsibility or experience of BE activities within their organisation. Each group was given specific aspects of BE to discuss and the findings were recorded via flip charts and hand-written notes. The workshops were also used as a tool to promote the questionnaire and clarify any questions or wording that may have been unclear.

\subsection{Interviews}

The final stage of data collection involved interviewing senior executives (mainly CEOs) of BE awardwinning organisations that had already completed the questionnaire. Interviewing award winners provided a unique perspective on the experiences and practices of organisations that have successfully deployed BE and provided clarification of their responses to the questionnaire. Thirteen interviews were conducted ( 3 each in Japan, Thailand, Singapore and India and 1 in the Republic of China). 


\subsection{Data Analysis}

With the quantitative data collected, the authors used the IBM SPSS Statistical software package to identify relationships between the data and address the research questions. The purpose of this study was a direct comparison of the use of independent tools and techniques between award winners and non-award winners. Therefore the most appropriate method of analysis was the use of direct descriptive statistical analysis. The qualitative data collected was mainly in the form of flip chart and hand-written notes from each of the discussion groups summarising the opinions of the groups as well as quotations from interviews of the chief executives. These notes and interview quotes were analysed within the context of the findings from the quantitative analysis in order to identify converging lines of enquiry by triangulating the data sources as suggested by Yin (2009). Consequently, the adoption of multiple sources of data comprising both qualitative and quantitative data provides a strong basis for justification and verification of inferences drawn from this research (Gerring, 2006).

\section{Results and Discussion}

As discussed in the literature review, a classification system of 5 stages of BE maturity was developed to classify organisations based on their level of BE maturity. Based on this classification, $4 \%$ of the 74 respondents believed they were at the awareness level, $9 \%$ were at the understanding level, $30 \%$ were progressing, $43 \%$ were competence and $14 \%$ were advanced.

For the purpose of this study organisations from "awareness to understanding to progressing" levels of BE maturity were grouped together and labelled as having low BE maturity and organisations from "competence to advanced" were grouped together and labelled as having high BE maturity. Thirty of the 74 respondents were award winners, and the Pearson Chi-Squared test identified a strong association between the level of BE maturity (low or high) and whether the organisation was a BE award winner.

Therefore, the organisation's perceived level of BE Maturity is highly dependent on whether the organisation has been awarded a National BE Award. However, it is important to note that this is not the only factor; some non-Award Winners were highly mature in BE but were simply not interested in applying for the national Award and some Award Winners who won an Award many years ago had since lost focus and their maturity had declined.

The following section details and discusses the results related to the 4 research questions.

\subsection{Do highly mature BE organisations perform better than their less mature counterparts?}

Respondents were asked to rate their current performance in 7 business areas on a scale of 0 to 10 (with 0 being very poor, 2 being below average in industry, 5 being average in industry, 8 being above average in industry and 10 being world class). The 7 business areas (which were the Result Items from the Baldrige Criteria for Performance Excellence) were:

1. Product and service results, 
2. Customer-focused results,

3. Financial and market results,

4. Workforce-focused results,

5. Process effectiveness results,

6. Leadership results, and

7. Social responsibility results.

For each of these areas, the means of the low BE maturity organisations were compared with the means of the high BE maturity organisations. In every business area, the organisations with high $B E$ maturity had greater mean values, as shown by table 6 .

\begin{tabular}{|l|l|l|l|l|l|l|l|}
\hline & $\begin{array}{l}\text { Product and } \\
\text { Service Results }\end{array}$ & $\begin{array}{l}\text { Customer } \\
\text { Focused } \\
\text { Results }\end{array}$ & $\begin{array}{l}\text { Financial } \\
\text { and Market } \\
\text { Results }\end{array}$ & $\begin{array}{l}\text { Workforce } \\
\text { Focused } \\
\text { Results }\end{array}$ & $\begin{array}{l}\text { Process } \\
\text { Effectiveness } \\
\text { Results }\end{array}$ & $\begin{array}{l}\text { Leadership } \\
\text { Results }\end{array}$ & $\begin{array}{l}\text { Social } \\
\text { Responsibility } \\
\text { Results }\end{array}$ \\
\hline $\begin{array}{l}\text { Low Maturity } \\
\text { Organisations } \\
\text { Mean }\end{array}$ & 7.17 & 6.96 & 7.16 & 6.60 & 6.56 & 6.88 & 6.92 \\
\hline $\begin{array}{l}\text { High Maturity } \\
\text { Organisations } \\
\text { Mean }\end{array}$ & 8.15 & 8.20 & 7.90 & 7.85 & 7.61 & 8.12 & 7.49 \\
\hline
\end{tabular}

Table 6: Comparing the means of business performance between organisations with different levels of BE maturity

To explore this relationship further, the Pearson Chi-Square test was used to identify associations between the level of maturity and current organisational performance. Associations with a significance value of less than 0.05 are deemed to be statistically significant and the results are shown in table 7.

\begin{tabular}{|l|l|l|}
\hline Business Area & Significance & Result \\
\hline Product and Service Results & 0.018 & Association \\
\hline Customer Focused Results & 0.019 & Association \\
\hline Financial and Market Results & 0.245 & No association \\
\hline Workforce Focused Results & 0.019 & Association \\
\hline Process Effectiveness Results & 0.089 & No association \\
\hline Leadership Results & 0.008 & Association \\
\hline Social Responsibility Results & 0.562 & No association \\
\hline
\end{tabular}

Table 7: The associations between level of BE maturity and business performance

The results show that there are significant relationships between an organisation's level of BE maturity and their product and service results, customer-focused results, workforce focused results and leadership results. Findings from the discussion groups and structured interviews supported these results. At the discussion groups participants completed an exercise to identify current and emerging challenges and whether the BE models addressed these or if the models needed to be redesigned. The consensus opinion was that the models were highly relevant and that if organisations successfully deploy BE they are more likely to achieve results that help them to tackle current and future challenges. Further support came from a discussion group held in Thailand which concluded that the emphasis on benchmarking within the context of BE encourages organisations to identify and implement best practices and, consequently, improve their own performance. The link between $\mathrm{BE}$ and success was also noted during the structured interviews; the director of an awardwinning large organisation confirmed that BE had increased the organisation's focus on excellence, whilst the director of a large service organisation in Thailand stated that BE had enabled the 
organisation to meet both its short and long-term goals. These results provide partial support for the findings of other studies that have found that organisations that win BE awards achieve better results than those that don't win awards (Hendricks and Singhal, 1997, Jacob et al., 2004, Kumar et al., 2009). However, this study goes further and finds that significant differences in performance do not occur across all aspects of performance.

Therefore, the results show that there is no statistically significant evidence that financial and market results, process effectiveness results and social responsibility results depend on an organisation's level of BE Maturity. There could be a variety of reasons for this last finding. One potential reason could be that the sample size was not large enough to identify a difference that was statistically significant (for example, "Process Effectiveness" was particularly close to being a statistically significant result and may well have been significant if a larger sample size had been used). Another reason could be that many factors impact on financial and market results that are outside of the organisation's control, whilst "Social Responsibility Results" may be affected more by government interventions and standards rather than by $\mathrm{BE}$.

In summary, the findings from Tables 6 and 7 suggests that adopting BE is likely to improve an organisation's performance for certain aspects of performance.

\subsection{Do the BE tools used by organisations depend on their level of BE maturity?}

The literature review revealed that there are a large number of potential tools that could be used by organisations when implementing BE. Twenty-four tools were chosen to be investigated; these 24 tools were selected based on their likelihood of being used and the likelihood of there being a common understanding of these tools across all participants.

Respondents were asked to select the BE tools they used on a regular basis from the list of 24 tools. A description of each tool was given to ensure the participants had the same understanding of the tool.

The study used the Pearson Chi-Square test to identify the relationships between the level of BE maturity and the tools used, with the results shown in table 8 .

\begin{tabular}{|l|l|l|}
\hline Tool & Significance & Result \\
\hline Informal Benchmarking & 0.023 & Association \\
\hline Performance Benchmarking & 0.001 & Association \\
\hline Best Practice Benchmarking & 0.002 & Association \\
\hline Balanced Scorecard & 0.697 & No association \\
\hline Business Process Re-engineering (BPR) & 0.088 & No association \\
\hline Corporate Social Responsibility (CSR) System & 0.928 & No association \\
\hline Customer (Client) Surveys & 0.468 & No association \\
\hline Employee Surveys & 0.421 & No association \\
\hline Environmental management system & 0.340 & No association \\
\hline Employee Suggestion Scheme & 0.577 & No association \\
\hline Improvement Teams & 0.053 & No association \\
\hline Knowledge Management & 0.015 & Association \\
\hline Lean & 0.021 & Association \\
\hline Mission and Vision Statement & 0.022 & Association \\
\hline Plan-Do-Check-Act (PDCA) & 0.403 & No association \\
\hline
\end{tabular}




\begin{tabular}{|l|l|l|}
\hline Quality Circle & 0.399 & No association \\
\hline Quality Cost & 0.007 & Association \\
\hline Quality Function Deployment (QFD) & 0.223 & No association \\
\hline Quality Management System & 0.391 & No association \\
\hline Six Sigma & 0.614 & No association \\
\hline SWOT Analysis & 0.041 & Association \\
\hline Total Productive Maintenance & 0.014 & Association \\
\hline 5S & 0.064 & No association \\
\hline BE Self-assessments & 0.038 & Association \\
\hline
\end{tabular}

Table 8: The associations between level of BE maturity and the BE tools used

The results show that there are relationships between the level of an organisation's BE maturity and the tools they use, with highly mature BE organisations likely to use more tools. Ten tools, as follows, show a significant relationship; Informal Benchmarking, Performance Benchmarking, Best Practice Benchmarking, Knowledge Management, Lean, Mission and Vision Statement, Quality Cost, SWOT Analysis, Total Productive Maintenance and BE Self-assessments. These results bear resonance with a study of UK and Irish organisations by McAdam and Jackson (2002). Their study found that there was a difference in levels of utilisation of process management techniques depending on the level of quality maturity of the organisation concerned. The key suggestion, therefore, is that the findings from Asia and earlier findings from Europe both confirm that there is an association between levels of $B E$ maturity and the level of use of improvement tools.

Figure 3 provides further analysis by summarising the percentage of organisations in both maturity categories that utilise each of the BE tools. It shows all tools were used by more organisations of high BE maturity except for customer surveys and suggestion schemes. Even though customer surveys and suggestion schemes were used more by organisations of low BE maturity this result was not statistically significant. Of interest is that over $70 \%$ of highly mature BE organisations used the following 15 tools: Informal Benchmarking, Performance Benchmarking, Best Practice Benchmarking, Corporate Social Responsibility System, Customer Surveys, Employee Surveys, Environmental Management System, Improvement Teams, Knowledge Management, Vision and Mission Statement, Plan Do Check Action, Quality Management System, SWOT Analysis, 5S and BE Self-assessments.

\section{[INSERT FIGURE 3 HERE]}

Figure 4 summarises the information in Table 8 and Figure 3. It shows the 60 tools initially considered by the APO/NPO Steering Group, the 24 selected for investigation, the 10 tools that are used more frequently by organisations of high BE maturity, and the 15 tools that are used by more than $70 \%$ of organisations with high BE maturity. The order by which the tools are placed within each category of BE in figure 4 is arbitrary and does not reflect the order with which they should be implemented. The arrows in the middle of the figure represent the stages of BE maturity and serve as a general guide to indicate that when an organisation implements more tools they are likely to advance in terms of BE maturity. These results compare with the findings of Haffer and Kristensen (2008) who found that Polish companies (that only partly applied BE practices) were not as mature as Danish companies (which applied BE practices fully); as a result the Polish companies did not achieve the same level of organisational performance.

\section{[INSERT FIGURE 4 HERE]}


The 10 tools in Table 8 that are more likely to be used by highly mature BE organisations could be considered as the differentiators that help BE organisations to move from low to high BE maturity. Most of these are from the category "Measurement, Analysis and Knowledge Management". The tools in this category help organisations to understand their currents systems and performance (for example, Quality Costs, BE Self-assessments and Performance Benchmarking), learn from other organisations on how to improve (Informal and Best Practice Benchmarking) and ensure this knowledge is captured, shared and retained (Knowledge Management). A surprising result was that Mission and Visions Statements and SWOT Analysis were also shown to be used more by highly mature BE organisations, as these tools are usually considered as standard tools for all organisations irrespective of BE maturity.

Based on these findings it is recommended that organisations wishing to improve their BE maturity should consider implementing all of the 15 tools that are used by more than $70 \%$ of organisations with high levels of BE maturity. They should also implement Lean, Quality Cost, and Total Productive Maintenance as these tools are also used significantly more in organisations with high BE maturity.

\subsection{Does the effectiveness of BE tools vary depending on the level of BE maturity?}

Of the 24 tools identified, respondents were asked to classify their perceived effectiveness on a scale of 1 to 4 ( 1 being not effective, 4 being majorly effective). The Pearson Chi-Square test was used to identify associations between the level of BE maturity and the effectiveness of the tools used, with the results shown in table 9.

\begin{tabular}{|l|l|l|}
\hline Tool & Significance & Result \\
\hline Informal Benchmarking & 0.468 & No association \\
\hline Performance Benchmarking & 0.235 & No association \\
\hline Best Practice Benchmarking & 0.173 & No association \\
\hline Balanced Scorecard & 0.026 & Association \\
\hline Business Process Re-engineering (BPR) & 0.117 & No association \\
\hline Corporate Social Responsibility (CSR) System & 0.124 & No association \\
\hline Customer (Client) Surveys & 0.044 & Association \\
\hline Employee Surveys & 0.225 & No association \\
\hline Environmental management system & 0.629 & No association \\
\hline Employee Suggestion Scheme & 0.226 & No association \\
\hline Improvement Teams & 0.083 & No association \\
\hline Knowledge Management & 0.019 & Association \\
\hline Lean & 0.912 & No association \\
\hline Mission and Vision Statement & 0.057 & No association \\
\hline Plan-Do-Check-Act (PDCA) & 0.559 & No association \\
\hline Quality Circle & 0.489 & No association \\
\hline Quality Cost & 0.399 & No association \\
\hline Quality Function Deployment (QFD) & 0.609 & No association \\
\hline Quality Management System & 0.372 & No association \\
\hline Six Sigma & 0.983 & No association \\
\hline SWOT Analysis & 0.071 & No association \\
\hline Total Productive Maintenance & 0.646 & No association \\
\hline 5S & 0.771 & No association \\
\hline BE Self Assessments & 0.004 & Association \\
\hline Table 9: The associations between level of BE maturity and the effectiveness of BE tools \\
\hline
\end{tabular}


The results of table 9 show that there are relationships between an organisation's level of BE maturity and the effectiveness of the Balanced Scorecard, BE self assessment, Customer Surveys, and Knowledge Management tools. It would be expected that organisations that were more mature would indicate higher levels of effectiveness for most BE tools as their staff are more likely to be supportive of change, better trained and have more information available to them on their processes and systems which would enable the effective use of BE Tools. It is therefore difficult to fathom why only 4 of these tools were shown as more effective for more mature organisations. As Conti (2004) has described organisations can successfully adopt improvement tools without aligning themselves to a BE award but from the authors' point of view a difference would be expected over a large sample of organisations. A more in-depth study on this topic would be useful to undertake in the future.

The results suggest that organisations with low BE maturity will be able to improve the effectiveness of these 4 tools as they become more mature and also by using a larger number of BE tools as identified in preceding sections. A common theme from the structured interviews was that $\mathrm{BE}$ helped the organisations to align and consolidate the use of improvement tools with their strategy. As one organisation explained "We leverage on our BE framework so that we have a strong foundation of operating systems, measurements, and controls to ensure operational excellence across processes, geographies, and business units".

\subsection{Do BE strategies used by organisations depend on their level of BE maturity?}

Respondents were asked questions about their strategic approach to BE deployment; in particular they were asked whether they agreed with a number of statements. Table 10 summarises the associations between the level of BE maturity and strategies used.

\begin{tabular}{|c|c|c|}
\hline Approach to BE & Significance & Result \\
\hline \multicolumn{3}{|l|}{ Education and training } \\
\hline $\begin{array}{l}\text { Education and training programmes on } \mathrm{BE} \text { are provided to a few of } \\
\text { our staff. }\end{array}$ & 0.236 & No association \\
\hline $\begin{array}{l}\text { Education and training programmes on } \mathrm{BE} \text { are provided to the } \\
\text { majority of our staff. }\end{array}$ & 0.000 & Association \\
\hline $\begin{array}{l}\text { Education and training programmes on } \mathrm{BE} \text { are provided to our senior } \\
\text { management team. }\end{array}$ & 0.148 & No association \\
\hline $\begin{array}{l}\text { We use the BE model for reference purposes when developing our } \\
\text { own company's BE model/approach. }\end{array}$ & 0.133 & No association \\
\hline \multicolumn{3}{|l|}{ Type of assessments } \\
\hline We undertake BE self-assessments (internal assessments). & 0.038 & Association \\
\hline $\begin{array}{l}\text { We hire outside consultants who undertake BE assessments on our } \\
\text { company (external assessments). }\end{array}$ & 0.514 & No association \\
\hline $\begin{array}{l}\text { We are assessed when we apply for our national BE award (external } \\
\text { assessment) }\end{array}$ & 0.004 & Association \\
\hline \multicolumn{3}{|l|}{ Frequency of assessments } \\
\hline We assess our BE performance every year & 0.037 & Association \\
\hline We assess our BE performance every two years & 0.528 & No association \\
\hline We do not undertake regular BE assessments & 0.435 & No association \\
\hline \multicolumn{3}{|l|}{ Scope of assessments } \\
\hline We undertake one BE assessment that covers the whole organisation & 0.381 & No association \\
\hline $\begin{array}{l}\text { We undertake many BE assessments that cover our business units and } \\
\text { departments }\end{array}$ & 0.437 & No association \\
\hline \multicolumn{3}{|l|}{ Supporting structure for BE } \\
\hline We have category leaders & 0.054 & No association \\
\hline
\end{tabular}




\begin{tabular}{|l|l|l|}
\hline We have a number of Improvement Teams & 0.013 & Association \\
\hline $\begin{array}{l}\text { We implement and monitor improvement actions based on } \\
\text { assessment findings }\end{array}$ & 0.009 & Association \\
\hline We have one BE Team that oversee all BE activities & 0.253 & No association \\
\hline We have one person full-time on BE & 0.190 & No association \\
\hline We have a team of people full-time on BE & 0.329 & No association \\
\hline Senior managers are fully involved in BE & 0.000 & Association \\
\hline $\begin{array}{l}\text { We have Culture of excellence and do not require specific BE for it to } \\
\text { continue and prosper }\end{array}$ & 0.014 & Association \\
\hline
\end{tabular}

Table 10: The associations between levels of BE maturity and BE approach

Figure 5 below summarises the percentage of organisations (with both low and high BE maturity) that use a particular strategy. The results of table 10 and figure 5 show that there are a number of relationships between an organisation's level of BE maturity and the BE strategies they use. They confirm that highly mature BE organisations adopt different strategies than less mature counterparts. Therefore, based on the earlier argument that BE is not an independent practice but requires other resources for successful implementation (Bolboli and Reiche, 2013, Saunders et al., 2008), this study argues that BE mature organisations (which have been shown to achieve better business performance) are better able to deploy resources into the implementation of BE. This ability to deploy resources better raises the question of whether a Resource Based View (RBV) of BE implementation can be considered. RBV theory argues that an organisation which effectively makes use of the resources (both human and material) and competencies at its disposal can improve its level of competitiveness (Halley and Beaulieu, 2009, Minshall and Garnsey, 1999). According to RBV, the potential of an organisation to improve its competitiveness is related to its ability to leverage resources and competencies that are valuable, rare, inimitable and non-substitutable (Barney and Griffin, 1992). Therefore, while this study did not specifically set out to examine RBV theory in BE deployment, the results suggest that BE mature organisations are better than the less mature organisations when it comes to deploying certain resources. These resources are now discussed in more detail.

\section{[INSERT FIGURE 5 HERE]}

Education and training is one such approach that seems very different between the two groupsthe majority of the highly mature organisations $(76 \%)$ ensure that most of their staff receive education and training, whilst only a minority $(28 \%)$ of the less mature organisations give education and training (and this tends to be only to a few members of staff). This is likely to be due to less mature organisations not understanding $\mathrm{BE}$ or not having an organisational-wide commitment to $\mathrm{BE}$. For BE to be successful, everyone inside an organisation needs to be fully involved in its implementation, meaning every employee should receive training on a regular basis. This finding is similar to that of McAdam and Jackson (2002) who found that organisations that had implemented TQM are more likely to involve employees in their improvement efforts. The importance of training to all levels of management and employees was supported in the discussion groups. One area of concern was the need for training and/or publications to explain more clearly how companies can develop a BE culture and improve performance in the various $B E$ categories. As a result of this finding the APO commissioned the development of a two guidebooks to assist with the understanding and implementation of business excellence (Mann et al., 2012b, Mann et al., 2012a). 
The findings show that highly mature BE organisations are more likely to undertake a BE selfassessment, and this could indicate why their performance is superior. In many cases selfassessments can be more useful for encouraging and driving internal change and improvements than external award based assessments. This is because internal assessments usually involve a larger number of people, the strengths and opportunities for improvement are self-identified thereby increasing buy-in and the time between identifying opportunities for improvement and actions to address them is usually shorter than for an external assessment whereby the organisation may need to wait a number of months to obtain the feedback report. As the majority of highly mature organisations are those either in possession of or aiming to apply for a BE Award, highly mature BE organisations are likely to use such self-assessments to ensure they have achieved a high level of performance excellence before applying for an award. The less mature BE organisations might be less likely to use internal self-assessment for a number of reasons; for example, they may not be aware of the role of BE self-assessments in BE, there may also be few BE self-assessment tools available within their country/region, or they may simply not have a clear aim and strategy to improve their BE maturity. Research by van der Wiele et al. (2000) also warns that it may be unwise for less mature organisations to undertake a self-assessment as they "may be pushed down blind alleys and take initiatives that are not suited to their state of TQM development". This points to the need for clear guidelines on how to use self-assessments, when to use them and how to interpret and action self-assessment data. From the structured interviews there were many examples of how organisations used self-assessments to measure progress, drive improvements and align strategies and cultures between business units or with suppliers. One large award-winning organisation found the assessment aspect of $\mathrm{BE}$ to be so important that they automated the process and carried out assessments quarterly whilst a micro organisation (less than 20 employees) used them as a governance tool to guide all employees in understanding the business and ensuring nothing was missed, such as potential risks, when planning future strategy.

In a study of self-assessment practices in Europe and Australia, Van der Wiele and Brown (1999) found that key reasons for the adoption of self-assessment practices included finding opportunities for improvement, directing the improvement process and creating a focus on award-related TQM criteria. Their study also found a correlation between the use of self-assessment and improvements in organisational performance including process improvement and identification of best practices. The findings from this study are therefore supportive as they indicate a positive relationship between the adoption of self-assessment and the level of BE maturity. Choosing a suitable selfassessment approach may be difficult, however, as there are many different self-assessment tools (Ritchie and Dale, 2000) and therefore the role of the BE custodian is important in providing advice on which tool to use.

Another approach that differs between the groups is that highly mature BE organisations are more likely to be externally assessed than organisations of less maturity. This is either by external consultants or, more usually, by external evaluators when applying for a BE award. It is not surprising that organisations with a higher level of BE maturity apply more often for a BE award.

Highly mature BE organisations assess their BE performance on a regular basis (60\% of these organisations review their performance every year, and $20 \%$ every two years), whilst less mature BE organisations do not (only $38 \%$ review their BE performance every year, and $16 \%$ every two years); this is probably due to highly mature BE organisations recognising the importance of continually 
assessing and improving performance year on year. In addition, tracking BE performance over time is a necessity if an organisation wishes to win a BE Award. The importance of regular assessment was noted in the discussion groups. Participants in India proposed the development of an integrated assessment programme with different types of assessment tools recommended for different levels of BE maturity. This finding was supported by other countries with Thailand emphasising the need for "clear steps that help companies to advance towards business excellence".

Highly mature BE organisations appear to have a more structured approach to BE. These organisations are more likely to have category leaders who are responsible for improving performance in a particular category, use improvement teams, and ensure improvement actions are identified and implemented following on from a BE assessment. As one company in Japan explained: "We set our own assessment indicators in each category and also implement benchmarking with other companies to improve in these areas. The indicators include examples such as the ratio of establishing management visions/policies, employee satisfaction ratio, the ratio of revealing information, the ratio of energy consumption reduction, the ratio of development of techniques/skills....". This more structured approach is likely to be a key reason for highly mature BE organisations out-performing their less mature counterparts. This finding is supported by Bolboli and Reiche (2013) who proposed a roadmap for BE implementation and argued that a structured approach is more likely to lead to sustainable BE development.

Senior managers in the highly mature BE organisations are much more likely to be fully involved in $\mathrm{BE}(79 \%)$ when compared to those in less mature organisations (38\%). This is probably due to them recognising that for $B E$ to be successful it must be led from the top with the leadership team setting an example to other employees. Less mature BE organisations, as identified in the discussion groups, were more likely to consider BE as an initiative or a project rather than an over-arching approach to improvement that needed the full commitment of the leadership team to succeed. The importance of leadership was very prominent in the discussion groups. The discussion group in India highlighted the need for greater involvement of senior executives in BE in order to improve success and the need for BE to be taught in leadership programmes. The Japanese discussion group asserted the importance of buy-in from key executives and, in particular, the next generation or prospective chief executive officers. In Thailand, the discussion group proposed the setting up of a discussion and sharing forums for chief executives in order to overcome the barriers of implementing and sustaining $B E$.

The relationship between leadership commitment and BE maturity was highlighted in the interviews. The chief executive of a BE award-winning SME in Singapore was planning to become an assessor for $\mathrm{BE}$ awards as this was considered to be a personal growth opportunity for the chief executive. In another award winning organisation in Singapore they has pushed BE down to their suppliers as they had recognised the need for the whole supply chain to improve if their own performance was to continue to improve. In an award-winning organisation in India, BE had been initially adopted voluntarily by one division of the organisation. However, after the division achieved success, the chairman of the organisation bought into BE and made it an organisation-wide initiative.

Finally, there is a difference in whether organisations believe that they have a culture of excellence within their organisation that does not require them to use specific BE tools and techniques in order for the organisation to prosper. The results show that highly mature BE organisations are more likely 
to feel this way; this suggests, and was given as a reason in some of the interviews, that once organisations reach a certain level of excellence then BE becomes ingrained in the culture and becomes the normal way of doing business. Examples of written comments received in the questionnaire to support this were "We do not deliberately distinguish business excellence as a separate activity. Rather, it is part and parcel of how we do our business" and "Business excellence is 'seen' as a project when we prepare for the application and assessment. Otherwise, the approach is part of what we normally do".

These findings suggest that organisations wishing to improve their level of BE maturity should look at implementing these approaches alongside the tools identified in preceding sections.

\section{Conclusion}

This paper has compared two types of Asian organisation; those that are highly mature in BE and those that are less mature. The research has identified differences in organisational performance, approaches for BE deployment both in terms of strategies and tools used and the relative effectiveness of BE tools between the two types of organisation.

The results have shown that $\mathrm{BE}$ improves the performance of Asian organisations and also highlighted the BE deployment strategies and tools that can improve an Asian organisation's level of BE maturity. Table 4 and figure 4 in particular are useful in showing what stage an organisation is currently at, as well as the tools and approaches that should be considered in order to become a more mature BE organisation. The results have shown that it is not simply about the BE tools that the organisation adopts - moreover, it is the strategy for BE deployment that helps to make an organisation more competitive.

The answers to the research questions posed earlier are shown below.

\section{Do highly mature BE organisations perform better than their less mature counterparts?}

Yes; on average, organisations with high BE maturity achieved higher levels of organisational performance than their low maturity counterparts in all 7 of the business result areas. However, only 4 of these business results areas were statistically significant.

2. Do the BE tools used by organisations depend on their level of BE maturity?

Yes, organisations with high BE maturity utilise more advanced BE tools. Of the 24 tools researched, 10 were more likely to be used by organisations with high BE maturity.

3. Does the effectiveness of BE tools vary dependent on the level of BE maturity?

For most tools there was no statistical difference in terms of effectiveness between low and high BE mature organisations. The exceptions were Knowledge Management, Customer Surveys, Balanced Scorecard and BE Self-assessments which were all rated as more effective in highly mature BE organisations 


\section{Do BE strategies used by organisations depend on their level of BE maturity?}

Yes, many differences were found between the BE strategies used by the 2 types of organisation. From 20 statements concerning BE strategies there were 8 differences at a statistically significant level.

In summary, based on these findings, it is recommended that organisations with low BE maturity develop a planned approach to BE deployment that incorporates the tools and strategies that were found to be used significantly more often by organisations with high BE maturity.

For business implications, the study has assisted the APO and its 20 member countries to develop and implement strategic interventions at a regional and national level. In particular, the APO's Centre for Business Excellence (located in Singapore) is using the research findings to determine how it can best help the NPOs. A number of interventions supporting this have already been conducted including workshops to up-skill the administrators of the various awards, workshops for BE consultants and evaluators and the publication of a BE Awareness Guidebook (Mann et al., 2012a) and BE Implementation Guidebook (Mann et al., 2012b). The guidebooks share some of the authors' research findings in order to help organisations to progress from a low level of BE maturity to a more advanced level.

The study's limitations are as follows: only 5 Asian regions were considered due to the greater use of $\mathrm{BE}$ in these regions. It would be interesting to conduct similar research in the rest of Asia and the world and investigate the impact that the business environment, culture and the services provided by $B E$ administrators in different countries have on BE deployment strategies and tools. One of the challenges of conducting research in countries with different languages is the increased likelihood of miscommunication. The questionnaire for this study was translated into Chinese, Thai and Japanese; however, even though proficient translators were used there is a small possibility that some technical terms in the questionnaire were misunderstood. The authors attempted to minimise this by holding discussion groups in each country whereby participants could clarify the meaning of terms or questions through the use of an interpreter.

Another potential limitation was the reliance on each organisation to accurately record their current level of BE maturity. To facilitate this, clear instructions were provided in the questionnaire and discussed in detail at the discussion groups. Ideally BE scores would have been validated via external assessments however this would have been too costly to consider. Finally, due to the small sample size (74 organisations completed the questionnaire) it was necessary to group organisations with "awareness to understanding to progressing" levels of BE maturity and label them as low maturity BE organisations and group organisations from "competence to advanced" and label them as high maturity BE organisations. Ideally these would not have needed to be grouped, allowing changes that occur between each stage of BE maturity to be investigated. Future research utilising larger sample sizes would prove interesting, as would comparing the results of this research with similar organisations in a different region (such as Europe or the USA). A country-by-country comparison would also be of interest. Future studies could also specifically test the application of RBV in the implementation of BE. 


\section{References}

ADEBANJO, D. 2001. TQM and Business Excellence: Is There Really a Conflict? Measuring Business Excellence, 5, 37-40.

ADEBANJO, D., ABBAS, A. \& MANN, R. 2010. An Investigation of the Adoption and Implementation of Benchmarking. International Journal of Operations \& Production Management, 30, 1140-1169.

ADEBANJO, D. \& MANN, R. 2008. Business Excellence. BPIR Management Brief. Palmerston North, New Zealand: BPIR.

ARUMUGAM, V., OOI, K.-B. \& FONG, T.-C. 2008. TQM practices and quality management performance: An investigation of their relationship using data from ISO 9001:2000 firms in Malaysia. The TQM Journal, 20, 636-650.

ASIF, M., SEARCY, C., GARVARE, R. \& AHMAD, N. 2011. Including sustainability in business excellence models. Total Quality Management \& Business Excellence, 22, 773-786.

BARNEY, J. B. \& GRIFFIN, R. W. 1992. The Management of Organizations: Strategy, Structure, Behavior, Boston, Houghton Mifflin Company.

BAUER, J., FALSHAW, R. \& OAKLAND, J. S. 2005. Implementing Business Excellence. Total Quality Management, 16, 543-553.

BLACK, K. \& REVERE, L. 2006. Six Sigma arises from the ashes of TQM with a twist. International Journal of Health Care Quality Assurance, 19, 259-266.

BLAZEY, M. L. 2011. Insights to Performance Excellence 2011-2012: Understanding the Integrated Management System and the Baldrige Criteria, American Society for Quality.

BOLBOLI, S. A. \& REICHE, M. 2013. A model for sustainable business excellence: implementation and the roadmap. The TQM Journal, 25, 331-346.

BOULTER, L., BENDELL, A., SINGHAL, V., ABBAS, H. \& DAHLGAARD, J. J. 2005. Report on EFQM, BQF Funded Project into the impact of the Effective Implementation of Organisational Excellence Strategies on Key Performance Results. Leicester, UK: EFQM and BQF.

BROWN, M. G. 2013. Baldrige Award Winning Quality: How to Interpret the Baldrige Criteria for Performance Excellence Boca Raton, Florida, CRC Press.

CONTI, T. 2004. How to Conceptually Harmonize ISO 9000 Certification, Levels of Excellence Recognition and Real Improvement. Total Quality Management \& Business Excellence, 15, 665-677.

CROSBY, P. 1979. Quality is Free, Milwaukee, WI, Quality Press.

DAHLGAARD, J. J., CHEN, C.-K., JANG, J.-Y., BANEGAS, L. A. \& DAHLGAARD-PARK, S. M. 2013. Business excellence models: limitations, reflections and further development. Total Quality Management \& Business Excellence, 24, 519-538.

DAHLGAARD-PARK, S. M. 2011. The quality movement: Where are you going? Total Quality Management \& Business Excellence, 22, 493-516.

DALE, B. 2003. Managing Quality, Oxford, Blackwell Publishers.

DALE, B. G. 1996. Benchmarking on total quality management adoption: a positioning model. Benchmarking for Quality Management \& Technology, 3, 26-37.

DALE, B. G. \& LASCELLES, D. M. 2007. Levels of TQM adoption. In: DALE, B. G., VAN DER WEILE, T. \& VAN IWAARDEN, J. (eds.) Managing quality. 5th Edition ed. Malden, MA: Blackwell Publishing Ltd.

DALE, B. G. \& SMITH, M. 1997. Spectrum of quality management implementation grid: development and use. Managing Service Quality, 7, 307-11. 
EFQM. 2012. The EFQM Excellence Model: Fundamental Concepts [Online]. Available: http://www.efqm.org/en/tabid/169/default.aspx [Accessed 04 January 2012.

EVANS, J. R. \& LINDSAY, W. M. 2005. An Introduction to Six Sigma \& Process Improvement, Cincinnati, $\mathrm{OH} .$, , Thomson South-western Publishing Company.

FOSTER, S., THOMAS 2010. Managing Quality: Integrating the Supply Chain, New Jersey, USA, Pearson.

GARVIN, D. 1991. How the Baldrige Award really works. Harvard Business Review, November- December (69), 98-111.

GEORGE, C., COOPER, F. \& DOUGLAS, A. 2003. Implementing the EFQM excellence model in a local authority. Managerial Auditing Journal, 18, 122-127.

GERRING, J. 2006. Case Study Research: Principles and Practices, New York, Cambridge University Press.

GRIGG, N. \& MANN, R. 2008. Review of the Australian Business Excellence Framework: A comparison of national strategies for designing, administering and promoting Business Excellence Frameworks. Total Quality Management \& Business Excellence, 19, 1173-1188.

HAFFER, R. \& KRISTENSEN, K. 2008. Developing versus developed companies in Business Excellence initiatives. Total Quality Management \& Business Excellence, 19, 763-775.

HAKES, C. 2011. Practical Excellence: A Hands-on Good Practice Guide to Obtaining Sustainable Excellence Through Using the EFQM Excellence Model and Participation in Related Global Business Awards, Leadership Agenda Limited.

HALLEY, A. \& BEAULIEU, M. 2009. Mastery of operational competencies in the context of supply chain management. Supply Chain Management: An International Journal, 14, 49-63.

HARRINGTON, H. J. \& LOMAX, K. C. 2000. Performance improvement methods: Fighting the war on waste, New York, NY, McGraw-Hil.

HENDRICKS, K. B. \& SINGHAL, V. R. 1997. Does Implementing an Effective TQM Program Actually Improve Operating Performance? Empirical evidence from organisations that have won quality awards. Management Science, 43, 12581274.

HUNG, R. Y. Y., LIEN, B. Y.-H., YANG, B., WU, C.-M. \& KUO, Y.-M. 2011. Impact of TQM and organizational learning on innovation performance in the high-tech industry. International Business Review, 20, 213-225.

HUQ, Z. \& STOLEN, J. D. 1998. Total quality management contrasts in manufacturing and service industries. International Journal of Quality \& Reliability Management, 15, 138-161.

JACOB, R., MADU, C. N. \& TANG, C. 2004. An empirical assessment of the financial performance of Malcolm Baldrige Award winners. International Journal of Quality \& Reliability Management, 21, 897-914.

KANJI, G. 2002. Measuring Business Excellence, London, Routledge.

KAYE, M. \& DYASON, M. 1995. The fifth era. The TQM Magazine, 7, 33-37.

KUMAR, V., CHOISNE, F., GROSBOIS, D. D. \& KUMAR, U. 2009. Impact of TQM on company's performance. International Journal of Quality \& Reliability Management, 26, 23-37.

KURUPPUARACHCHI, D. \& PERERA, H. S. C. 2010. Impact of TQM and Technology Management on Operations Performance. IUP Journal of Operations Management, 9, 23-47. 
LEE, P. 2002. Sustaining business excellence through a framework of best practices in TQM. The TQM Magazine, 14, 142-149.

LEONARD, D. \& MCADAM, R. 2002. The strategic impact and application of the business excellence model: implications for quality training and development. Journal of European Industrial Training, 26, 4-13.

MACLEOD, A. \& BAXTER, L. 2001. The contribution of business excellence models in restoring failed improvement initiatives. European Management Journal, 19, 392403.

MANN, R. 2008. Revisiting a TQM research project: The quality improvement activities of TQM. Total Quality Management \& Business Excellence, 19, 751-761.

MANN, R. 2011. Impact of Business Excellence/Quality Awards on Enterprises. In: ORGANISATION, A. P. (ed.). Tokyo, Japan.

MANN, R., ADEBANJO, D., LAOSIRIHONGTHONG, T. \& PUNNAKITIKASHEM, P. 2011a. Awareness and impact of business excellence in Asia. Total Quality Management \& Business Excellence, 22, 1237-1258.

MANN, R., ADEBANJO, D. \& TICKLE, M. 2011b. Deployment of business excellence in Asia: an exploratory study. International Journal of Quality \& Reliability Management, 28, 604-627.

MANN, R., MOHAMMAD, M. \& AGUSTIN, T. 2012a. Understanding Business Excellence An Awareness Guide for SMEs. In: ORGANISATION, A. P. (ed.).

MANN, R. S., MOHAMMAD, M. \& AGUSTIN, T. 2012b. Implementing Business Excellence - An Implementation GuideBook for SMEs. In: ORGANISATION, A. P. (ed.).

MCADAM, R. \& JACKSON, N. 2002. A sectoral study of ISO 9000 and TQM transitions- the UK and Irish brewing sector. Integrated Manufacturing Systems, 13, 255-263.

METAXAS, I. N. \& KOULOURIOTIS, D. E. 2014. A theoretical study of the relation between TQM, assessment and sustainable business excellence. Total Quality Management \& Business Excellence, 25, 494-510.

MINSHALL, T. \& GARNSEY, E. 1999. Building Production Competence and Enhancing Organizational Capabilities through Acquisition: The Case of Mitsubishi Electric. International Journal of Technology Management, 17, 312-333.

MOHAMMAD, M., MANN, R., GRIGG, N. \& WAGNER, J. P. 2011. Business Excellence Model: An overarching framework for managing and aligning multiple organisational improvement initiatives. Total Quality Management \& Business Excellence, 22, 1213-1236.

MOHAMMAD, M. \& MANN, R. S. 2010. National Quality / Business Excellence Awards in Different Countries [Online]. http://www.bpir.com. Available: http://www.bpir.com.

NATIONAL INSTITUTE OF STANDARDS AND TECHNOLOGY 2012. Malcolm Baldrige National Quality Award - Criteria for Performance Excellence 2011 - 2012. Gaithersburg, Maryland.

NATIONAL INSTITUTE OF STANDARDS AND TECHNOLOGY. 2013a. Baldrige Award Recipients' Contacts and Profiles [Online]. Gaithersburg, Maryland. Available: http://www.baldrige.nist.gov/Contacts Profiles.htm [Accessed 08 August 2013.

NATIONAL INSTITUTE OF STANDARDS AND TECHNOLOGY 2013b. Baldrige Criteria for Performance Excellence. In: EXCELLENCE, B. C. F. P. (ed.). Gaithersburg, Maryland.

NATIONAL INSTITUTE OF STANDARDS AND TECHNOLOGY. 2013c. Malcolm Baldrige National Quality Award - Criteria for Performance Excellence 2013 - 2014 [Online]. Gaithersburg, Maryland. Available: 
http://www.nist.gov/baldrige/publications/business nonprofit criteria.cfm [Accessed 10 July, 2013.

NAYLOR, G. 1999. Using the Business Excellence Model to develop a strategy for a healthcare organisation. International Journal of Health Care Quality Assurance, $12,37-44$.

OAKLAND, J. 2003. Total Quality Management. In: SEAVER, M. (ed.) Gower Handbook of Quality Management. Third ed. Aldershot: Gower.

OAKLAND, J. S. \& TANNER, S. J. 2008. The relationship between Business Excellence and Performance - An empirical study using Kanji's Leadership Excellence Model. Total Quality Management \& Business Excellence, 19, 733-749.

PATTON, M. 1987. How to use qualitative methods in evaluation, California, USA, Sage.

PETERS, J. 1994. Operationalizing total quality: a business process approach. The TQM Magazine, 6, 29-33.

PORTER, L. \& TANNER, S. 2004. Assessing Business Excellence, Oxford, UK, Elsevier Butterworth-Heinemann.

PRABHU, V., YARROW, D. \& GORDON-HART, G. 2000. Best practice and performance within Northeast manufacturing. Total Quality Management, 11, 113-122.

REHDER, R. \& RALSTON, F. 1984. Total Quality Management: A Revolutionary Management Philosophy. S.A.M. Advanced Management Journal, 49, 24-33.

RIGBY, D. 2011. Management Tools 2011 - An Executive's Guide. Boston, USA: Bain \& Company.

RIGBY, D. \& BILODEAU, B. 2013. Management Tools \& Trends. Boston, USA: Bain \& Company.

RITCHIE, L. \& DALE, B. G. 2000. Self-assessment using the business excellence model- A study of practice and process. International. Journal of Production Economics, 66, 241-254.

SALAHELDIN, S. I. 2009. Critical success factors for TQM implementation and their impact on performance of SMEs. International Journal of Productivity and Performance Management, 58, 215-237.

SAUNDERS, M. \& MANN, R. S. 2007. Business Excellence Tools: The Tools Used by Companies at Different Stages of Business Excellence Maturity. Palmerston North, New Zealand: Centre for Organisational Excellence Research.

SAUNDERS, M., MANN, R. S. \& GRIGG, N. P. 2008. Utilisation of business excellence models: Australian and international experience. The TQM Journal, 20, 651-663.

SLACK, N., BRANDON-JONES, A. \& JOHNSTON, R. 2013. Operations Management, Essex, UK, Prentice Hall.

SOWER, V., E. 2011. Essentials of Quality: With Cases and Experiential Exercises, New Jersey, USA, Wiley.

SPRING SINGAPORE 2010. Insights to Business Excellence. Bukit Merah Central, Singapore.

TALWAR, B. 2011. Business excellence models and the path ahead .... The TQM Journal, 23, 21-35.

TOSSAINT, I., L. 2010. Business Excellence at Philips.

TUTUNCU, O. \& KUCUKUSTA, D. 2009. Canonical correlation between job satisfaction and EFQM business excellence model. Quality \& Quantity, 44, 1227-1238.

VALMOHAMMADI, C. 2011. The impact of TQM implementation on the organizational performance of Iranian manufacturing SMEs. The TQM Journal, 23, 496-509. 
VAN DER WIELE, A., VAN IWAARDEN, J. D., DALE, B. G. \& WILLIAMS, A. R. T. 2007. Improvement approaches. In: B.G. DALE, A. V. D. W., \& J. VAN IWAARDEN (ed.) Managing quality. 5th Edition ed. Malden, MA: Blackwell Publishing.

VAN DER WIELE, A., WILLIAMS, A. R. T. \& DALE, B. 2000. ISO 9000 series registration to business excellence- the migratory path. Business Process Management Journal, 6, 417-427.

VAN DER WIELE, T. \& BROWN, A. 1999. Self-assessment practices in Europe and Australia. The International Journal of Quality \& Reliability Management, 16.

VORA, M. K. 2013. Business excellence through sustainable change management. The TQM Journal, 25, 625-640.

WANG, L. C. \& AHMED, K. P. 2001. Energizing the organization - a new agenda for business excellence. Measuring Business Excellence, 5, 22-27.

YANG, C.-C. 2009. Development of an integrated model of a business excellence system. Total Quality Management \& Business Excellence, 20, 931-944.

YIN, R. 2009. Case Study Research: Design and Methods, California, USA, Sage.

YONG, J. \& WILKINSON, A. 2001. In Search of Quality: The Quality Management Experience in Singapore. International Journal of Quality \& Reliability Management, 18, 813-835.

Figures

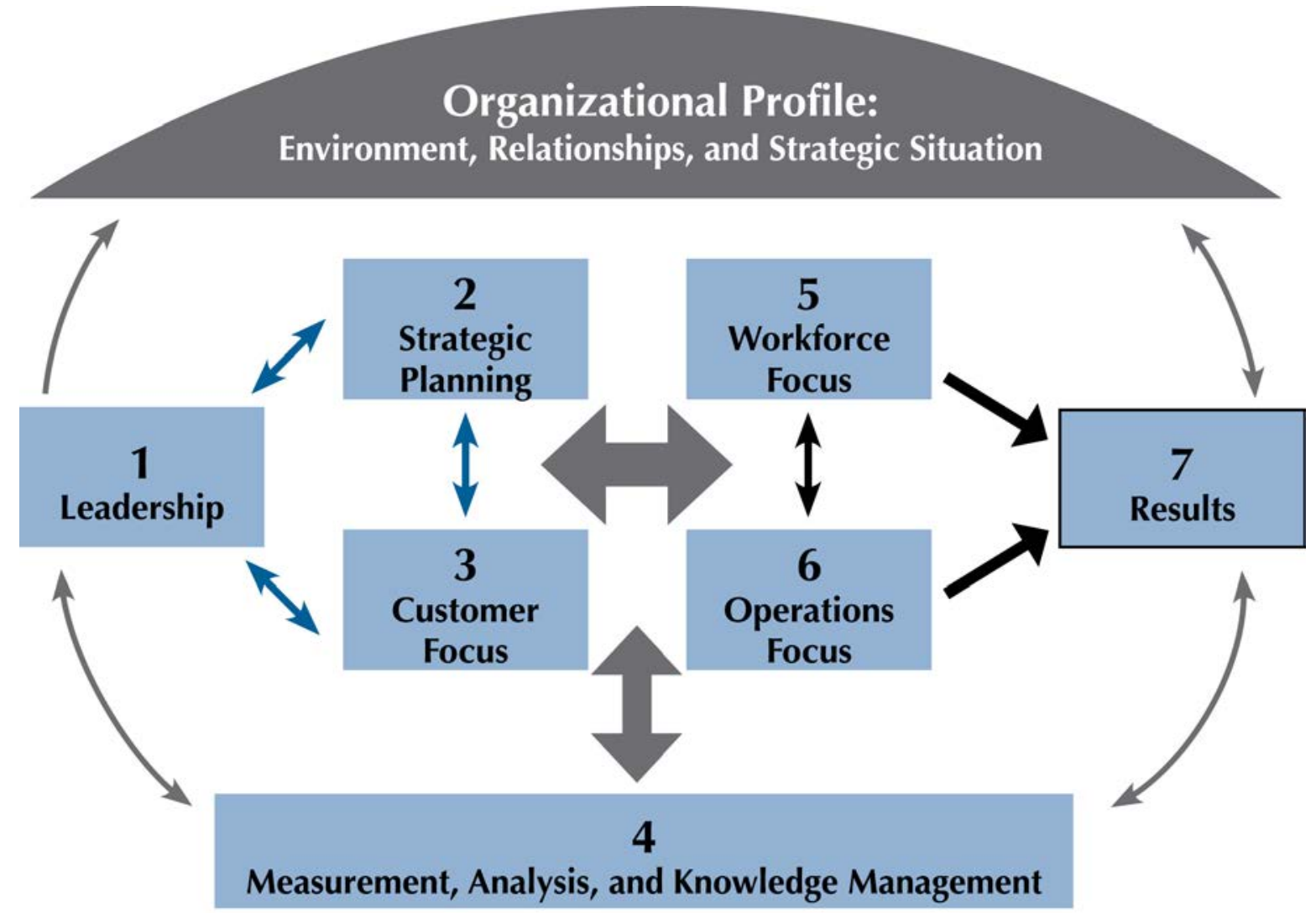

Figure 1: Baldrige Criteria for Performance Excellence (National Institute of Standards and Technology, 2013c) 


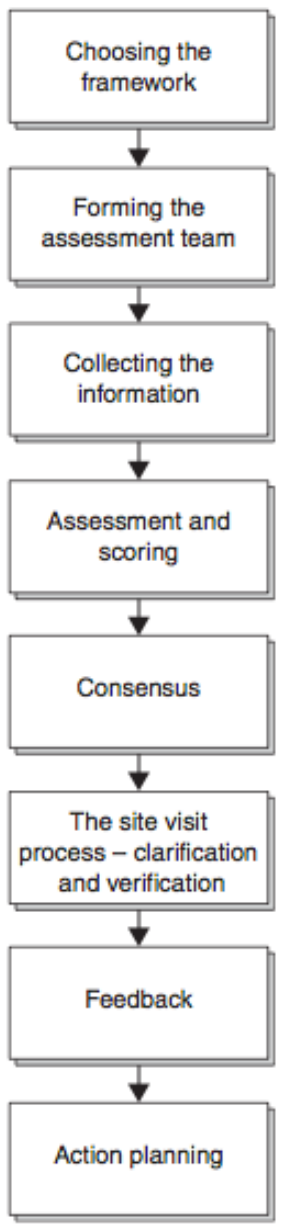

Figure 2: Self-assessment steps (Porter and Tanner, 2004) 


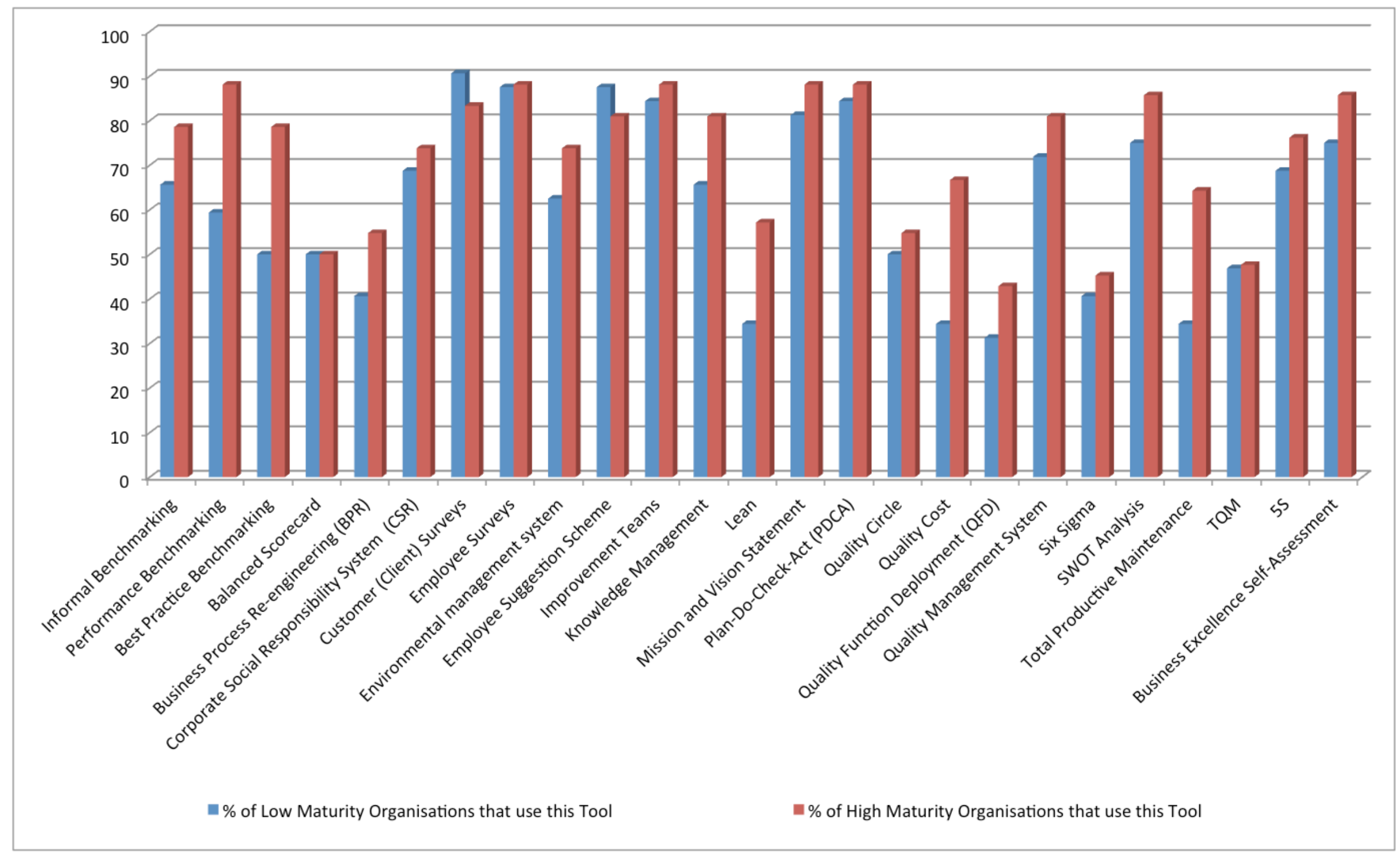

Figure 3: Comparing the tools used by organisations with low BE maturity and high BE maturity 


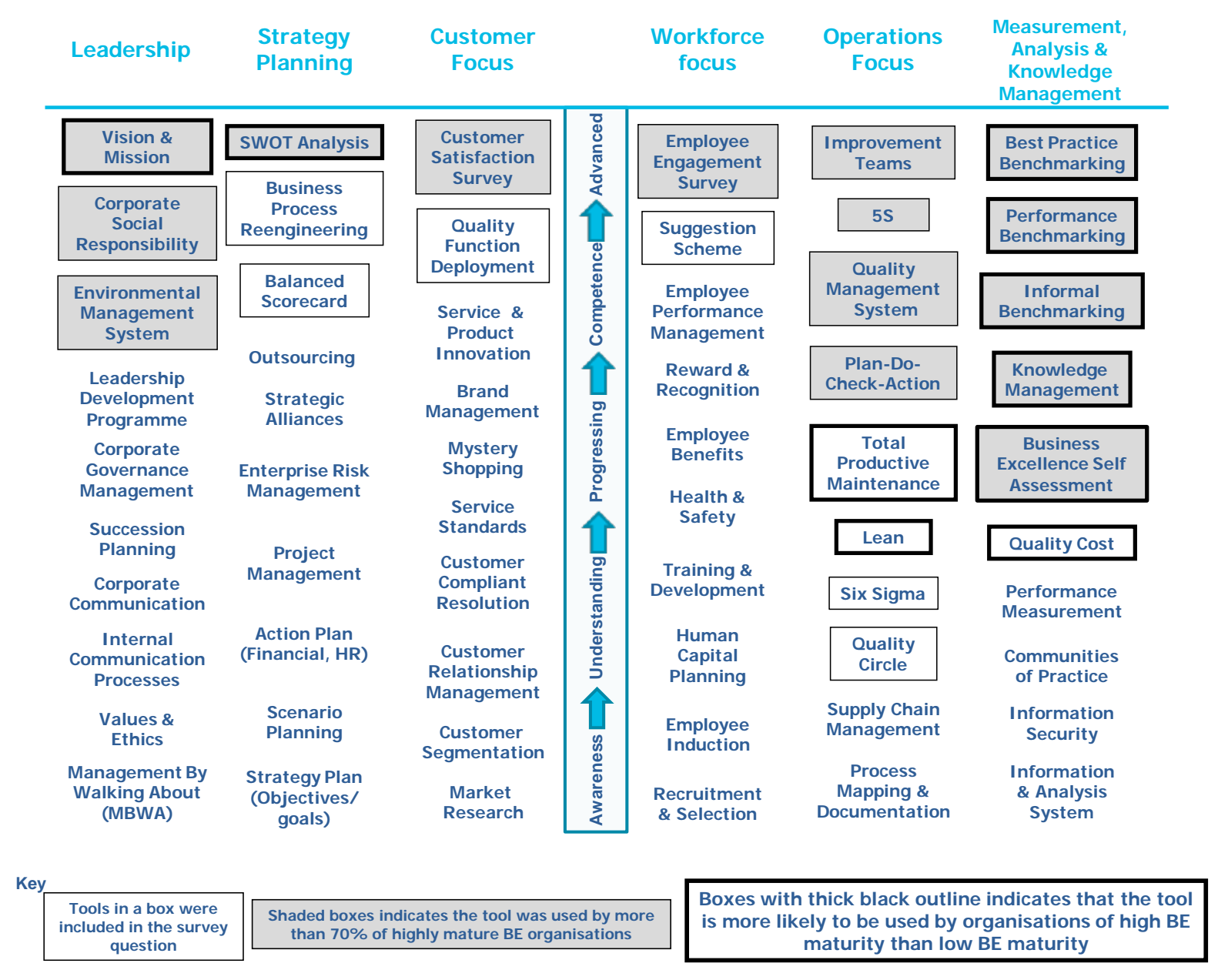

Figure 4: The BE tools split into categories and those that are used by organisation of high BE maturity identified 


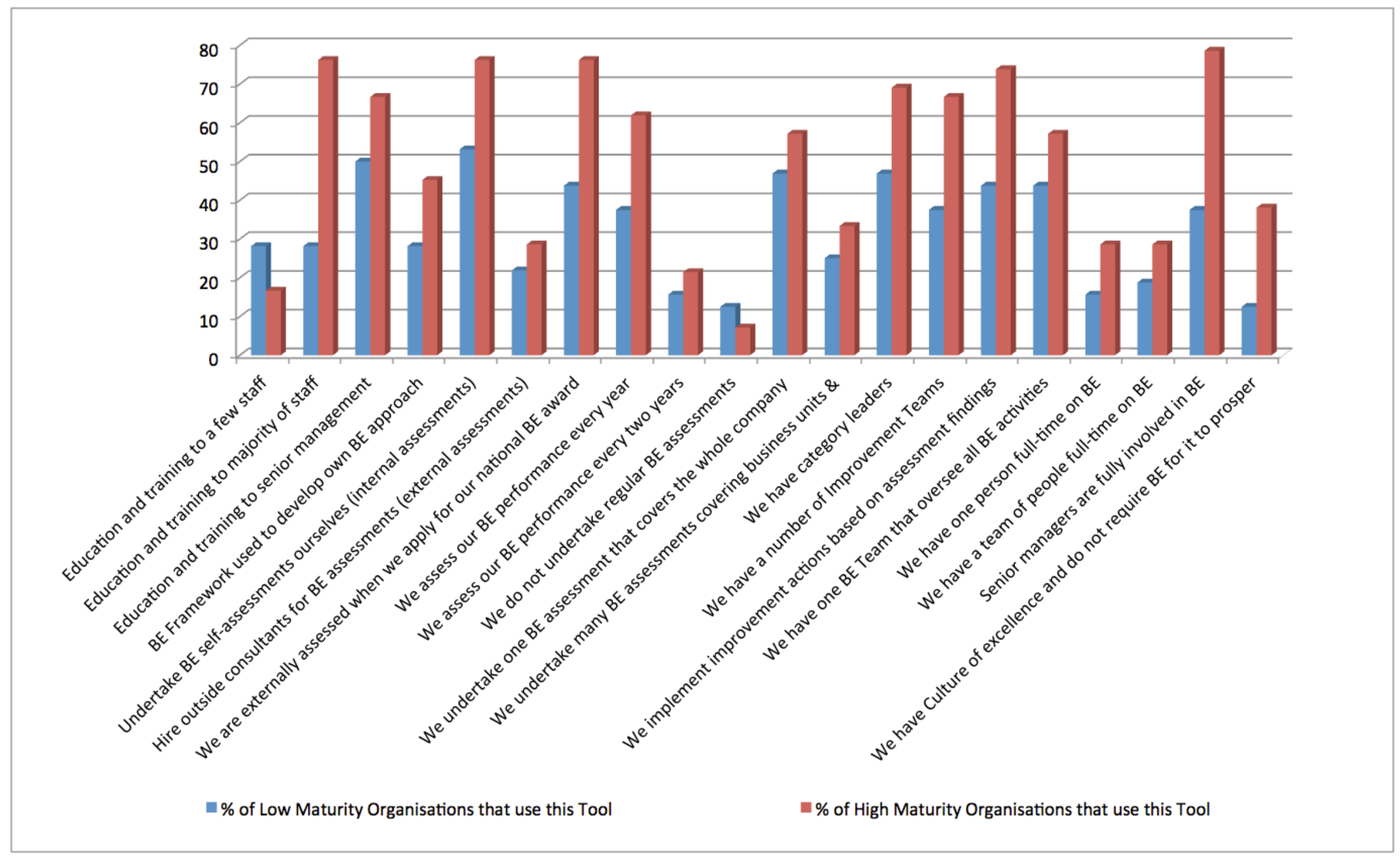

Figure 5: Comparing the BE approaches used by organisations with low BE maturity and high BE maturity 